\title{
AN ANALYSIS OF STUDIES ON TEACHING AND LEARNING READING IN INDONESIA
}

\author{
Syofia Delfi ${ }^{1)}$, Hamidah Yamat ${ }^{2)}$ \\ ${ }^{* 1)}$ University of Riau, Indonesia \\ ${ }^{* 2)}$ State University of Malaysia, Malaysia \\ email: syofia_delfi@yahoo.com
}

\begin{abstract}
Various studies on teaching and learning reading in Indonesia have been conducted. In order to know the strengths and the weaknesses of the studies, a thorough study is needed to be conducted. This article is based on a critical analysis on teaching and learning reading in Indonesia for a study "a Case Study on Two Indonesian Learners' Extensive Reading in English Experiences towards Developing Reading Competency". It aimed to answer: (1) What were the strengths and the weaknesses of the studies on teaching and learning reading in 2003 to 2013? (2) How were the studies similar and/ or different from the current study"? The critical analysis was conducted by studying twenty articles from 2003 until 2013. The studies were analyzed critically in terms of the strengths and the weaknesses. The findings of the analysis are; (1) The strengths of the studies on teaching and learning reading in 2003 to 2013 were in terms of the topic of the studies indicating that learning English in Indonesian context and the studies on extensive reading were developed gradually. The weaknesses were in terms of the focus of extensive reading and the variation of the research design. (2) The studies were similar with the current study in terms of the concept of extensive reading and the research design. This condition might be considered as an opportunity for the following researchers to conduct a research about learners' experiences on extensive reading. It is suggested that that teachers, lecturers and the policy makers on language learning concern about how extensive reading is implemented.
\end{abstract}

Key Words: reading teaching and learning reading, extensive reading

\section{ANALISIS PENGAJARAN DAN PEMBELAJARAN MEMBACA BAHASA INGGRIS DI INDONESIA}

\begin{abstract}
Abstrak
Bermacam-macam variasi kajian pada pembelajaran membaca dalam bahasa Inggris sudah dilakukan peneliti. Untuk mengetahui kelebihan dan kekurangan dari kajian tersebt perlu dilakukan kajian. Artikel ini berdasarkan analisis yang kritis untuk pembelajaran membaca di Indonesia untuk kajian "a Case Study on Two Indonesian Learners' Extensive Reading in English Experiences towards Developing Reading Competency". Analisis ini untuk
\end{abstract}


menjawab pertanyaan (1) Apa kelebihan dan kekurangan dari kajian tentang pembelajaran membaca di Indonesia pada tahun 2003 to 2013? (2) Bagaimana kajian dari 2003 until 2013 berbeda atau sama dengan kajian yang ini. How were the studies similar and/ or different from the current study"? Analisis secara kritis dilakukan untuk 20 kajian dari 2003 until 2013. Temuan yang diperoleh adalah; (1) Kelebihan dari kajian 2003 to 2013 adalah focus dari membaca secara ekstensif dan variasi rangan penelitan. 2) Kesamaannya adalah konsep dari membaca ekstensif. Kondisi ini member peluang untuk melakukan penelitian berdasarkan pengalaman mahasiswa dalam membaca ekstensif. Hasil kajian ini menyarankan bahwa guru, dosen, dan pembuat kebijakan pembelajaran untuk memperhatikan bagaimana membaca ekstensif bisa diterapkan.

Kata Kunci: membaca, pembelaran membaca, dan membaca ekstensif

\section{INTRODUCTION}

Reading is as one of a language skills gained through the process of learning a language. In Indonesia it is as the implication of the national curriculum and the reflection of its language policy. The language policy in Indonesia impacts on the students' context in learning English. Indonesian students learn English for fulfilling schools and university requirements. It is only used for international communication and specific purposes. The way how English is taught or how the students learn English indicates that English is only for learning and testing, it is not for using. It also reflects on how reading is taught and the role of reading. Learners begin to learn English after being competent in local language and Indonesian language or acquiring and learning the language. Lightbown and Spada (2011) point out that all second language and foreign language learners have already acquired at least one language.

Reading is a process of readers combining information from a text and their own background knowledge to build meaning (Anderson and Nunan, 2008). The meaning gained from reading contains alphabetic and sounds transferred from writer to readers ( Nuttall, 1982). Understanding meanings of texts is the important outcome of reading (Burnes and Page, 1985). The meaning of reading is classified into: meaning and understanding, knowledge of alphabetic, and knowledge of sounds (Byrness and Wasik, 2009). Gaining the meaning of texts is the readers' responsibility in order to make sense of texts.

Two basic approaches in reading are intensive and extensive reading (Brown, 2001; Harmer, 2007; and Anderson and Nunan, 2008). Learners experience learning reading from these approaches as long as teachers understand the differences between intensive and extensive reading. Intensive reading refers to reading usually done a way from classroom while extensive reading refers to the focus on the construction 
of reading texts which usually takes place out side of classroom.

Learners will gain the knowledge through reading (Hedge, 2008). It matches the context of Indonesian learners learning English through genre base which provides learners with text types in learning English. It is in line with what Hammer (2009) points out. He states that reading is useful for language acquisition since it provides students with reading materials higher or lower than the students' ability. It affects on the students' vocabulary knowledge, grammar, writing, speaking in terms of talking about the idea gained from texts read. It also implies that reading can also affect on listening since speakers and listeners involve in the discussion about the topic from texts. Lee and Hsu (2009) emphasize that reading is the source of good writing style because learners can learn vocabulary, syntax and discource structure of the written language.

Lewis and Reinders (2003) point out that one of reasons for learners to do reading is to improve English language as well as learning about subjects. What learners learn from reading are in terms of writing, increasing vocabulary, organizing idea. O'Donnell and Wood (2004) claim that a child has interest in reading based on the meaningful context of the text. They learn for this situation that reading provides pleasure and information. Aebersold and Field (2011) point out that readers' engagement in the reading process is based on their past experience. Both learning how to read and ways reading fit the learners' lives. The experiences help readers in doing the activities of reading. Nuttall (1982) also specifies that the purpose of reading is submerged by the purpose of language improvement. To the context of Indonesia, Subekti (2007) proves that the influence of reading is on acquiring and learning words. This is in line with the processes of second language reading classified by Hedge, (2008); interactive process, purposeful process and critical process.

In teaching reading, teachers may refer to reading models which are classified into; bottom-up, topdown, and interactive reading model (Hedgcock and Ferris, 2009). Hedge (2008) states that bottom-up processing have been used to describe the decoding of letters, words and other language features in the text. Carrell (1988), Mckoon \& Radcliff (1992) and Brown (2001) state that bottom-up model readers recognize a multiplicity of linguistic signals (letters, morphemes, syllables, words, phrases, grammatical cues, discourse markers). Silbestein points out that top down is knowledge-based occurs when readers prior knowledge to make predictions about the data they will find in a text. Anderson \& Nunan (2008) believe that readers in top down uses background knowledge makes predictions, and searches the text to confirm or reject the predictions that are made. The combination of bottom-up and topdown model is called interactive reading (Brown, 2001). He believes that both processes are important in successful teaching methodology because this approach has shown the 
use of bottom-up and top down approach.

Learners in the process of learning reading experience bottom up or top down model or both of these models or interactive model. It depends how they are taught. They may be provided with language feature or background knowledge for finding the idea or both of them. Researchers who are interested in reading conduct researches on reading based on these models. They may reflect on ways in gaining the leaners' reading ability in terms of language components or language skills, especially for reading and it is also the researchers' interest in conducting the current research. This is the writers' reason analyzing researches on teaching and learning reading as a part of a study on the exploration of the learners' extensive reading experience in order to see how it contributes to their English language competency and the practices in the Extensive Reading course. Therefore, this article attempts to explore; (1) What were the strengths and the weaknesses of the studies on teaching and learning reading in 2003 to 2013 ?

(2) How were the studies on teaching and learning reading in 2003 to 2013 similar and/ or different from the study on "a Case Study on Two Indonesian Learners' Extensive Reading in English Experiences towards Developing Reading Competency"?

\section{METHOD}

The analysis of researches on learning and teaching reading in this article is based on the analysis of 20 articles. The writers expect that the studies were published within ten years; from 2003 until 2013. Since it is difficult to find articles published before 2007, the writers only studied articles published from 2007 to 2013. The articles were studied critically in terms of the types of reading, the research methodology; research design, participants, research findings and the suggestion of the research. The procedures in analyzing the articles were; reading and rereading the articles, testing the response, transcribing in the form of table and writing the response. The result of the description was analyzed into themes in order to find the strength and weaknesses of the study. The themes are dealing with the topic area of the study.

\section{FINDINGS AND DISCUSSION}

This section provides reviews of the researches that have been undertaken in investigating learning English in Indonesia, in particular reading. This sections attempts to discuss the overall concepts of the researches. They are exposure to language learning in Indonesia. It is extended to describe the weaknesses of the previous research. This brief review thus serves as an orientation toward examining learning English in Indonesia, in particular reading with the aim of filling the gap in this area. It discusses about the language learning in Indonesia, especially reading, the weaknesses of the language learning in the past, the gap between the language learning in the past and the current study. The detail description of the classification of this study is described. 
There are various topics of the studies in Indonesia. The studies are about; (1) the different level of EFL readers in terms of their linguistic knowledge, text structure knowledge, content and world background knowledge, or reading strategies, (2) the differences in using reading strategies in Bahasa Indonesia and English, (3) the students' reading strategies, (4) the difficult types of Reading skills of EFL students, (5) the application of a teaching strategy, (6) the application of learning model, (7) developing teaching model, (8) drading Box for the students' interest, (9) developing reading material for character building, (10), the implementation of extensive reading task to improve the students' reading motivation (11) silent reading for reading comprehension, students' reading habit, (12) a model of reading teaching for University EFL, (13) technologically supported library for High School students' reading habits and skills, (14) online resources to cultivate reading habits and increase English literacy achievement, (15) developing reading comprehension materials for reading course. (16) teachers' questioning in reading lessons. Most of the types of reading studied were intensive reading. They were studied in different topics and different research-designs. These studies were conducted by researchers in different provinces in Indonesia. They are also mentioned in this session.

The participants are university, senior high school, junior high school, elementary school students and teachers. The topics which were close to extensive reading were reading habit and reading attitude. The studies about reading habits were formulated based on technology library, on line sources, and assignment. The research designs were action research, survey, experimental study, developmental study, descriptive study; comparative study, correlation, and case study. The studies indicate that the implementation of genre base approach were about the students' ability and methods or strategies for the students' ability. They were in terms of teachers' teaching strategy and the students' motivation. It also shows that researchers in Indonesia have tried to study the topics on developing reading habit by doing extensive reading. It seems that researchers are becoming interested in conducting studies on extensive reading.

The studies involved students and teachers as participants in order to gain the improvement of the students' ability. The studies about students as participants are in terms of students' ability and the implementation of strategies or methods by teachers for increasing their ability. The studies about teachers are in terms of teaching strategy for increasing the students' ability. These are as goals of the studies in order to have the students' ability in English as a target to have competency about the language components and language skills.

Various kinds of studies were conducted involving students as participants. It was begun by the study about the possible aspects happen to the students. The studies were about differences among the 
level of the students' ability, the students' difficulty, the strategy used by the students. Sulistyo and Suharmanto (2007) studied whether the different levels of students' ability EFL as readers of English Departments students of faculty of Letters were really different; ability of poor EFL readers, average and good EFL readers. The differences were observed in terms of their linguistic knowledge, text structure knowledge, content and world background knowledge, and reading strategies employed. They also want to know the established discrimination functions. The writers found that poor EFL readers, average EFL readers and good EFL readers really differ in terms of their linguistic knowledge, text structure knowledge, content and world background knowledge, or reading strategies employed. It means that those are the aspects indicating that one has the ability in understanding texts. If their ability is different ability means their ability in this component is not the same.

Sulistyo and Suharmanto (2007), Debora and Divina (2009) and Fitrawati (2009) suggest in different way. Sulistyo and Suharmanto (2007) suggest that teachers can activate the advanced EFL readers' schemata by doing pre reading activities and reading strategies in teaching reading. The study indicates that readers are expected to be able to explore their prior knowledge about the text that they are going to read. When readers explore their prior knowledge, they perform the similar linguistic knowledge and they can direct themselves to the structure of the texts while reading. These researchers thought that learners need to be trained to do pre-reading activities as well as reading strategy. Debora and Divina (2009) were really concerned about the students' difficulty. They suggest that the research could be reduplicated into a large scale with larger test items and respondents.

The previous researchers also conducted researches dealing with reading strategy used by students in the first language and English. Vianty (2007) conducted a study on the strategy used by students in reading Bahasa Indonesia and English. The objective of the study was to find out whether there were differences in using pragmatic reading strategies occurred when the students read in Indonesian (Bahasa Indonesia) and English. The results of the analyses proved that some differences exist in the use of pragmatic reading strategies for Indonesian (Bahasa Indonesia) and English. She thought that conducting such kind of the study is appropriate in Indonesian context. She suggested to reduplicate this kind of the study with larger samples and with more carefully constructed tests of reading. This study arouse the context in which Indonesian students read texts in national and foreign language are not the same in pragmatic reading strategies. It is the opportunity for EFL learners to practice reading the English texts in or to make learners be familiar with the English texts.

The other kind of study on reading strategy was about reading strategy used by English department students at university as a study conducted by Abidin \& Riswanto 
(2012). The study found that the students' reading strategies are Global Reading Strategies (GRS), Problem Solving Strategies (PRS), and Support Reading Strategies (SRS). The study found that the most strategy used by students was (GRS) and the least used strategy was Problem Solving Strategies (PSR) in reading. The study suggested that readers need to use strategies in accordance with the texts as well as reading purposes. It means that readers are expected to recognize texts in using the appropriate strategy. This reflects on the students' main problem in terms of text organization as discussed earlier. If the students recognize the text organization, the students know how to read the texts.

Some studies are about efforts in improving the students' ability. Miranti (2008) conducted a research on using the immediate written recall to enhance students' reading comprehension. She found that there is significant effect of level of testing on the students' comprehension score. She also found that there is significant effect of level of English proficiency on students' comprehension scores. Therefore, she suggested that "Immediate Written Recall" might be used to enhance the students' reading comprehension.

The other study conducted by Hamra \& Syatriana (2010) who suggested the different model. They suggested that Interactive Model of Teaching Reading Comprehension (IMTRC) be suitable for reading comprehension of the senior high school students. An action research in improving the students' social interaction by using the language learnt was conducted by Hamra \& Syatriana (2012). The study is "A Model of Reading Teaching for University EFL: Need Analysis and Model Design". They studied that the teaching model improves the reading comprehension of the students. Reading lectures or instructors can use this reading teaching model as an alternative teaching reading method to increase the reading comprehension of students and to improve their social interaction of them in the classroom and outside of the classroom.

Improving the students' reading ability for university students is as a study conducted by Martini's (2008). She studied the use of extensive reading as a task reading outside of the classroom to improve student's reading motivation at Accounting Department, Padang State Polytechnic. She conducted the study in order to find whether the implementation of extensive reading task successfully improve the students' reading motivation. The study found that the implementation of extensive reading task can successfully improve the students' reading motivation. Martini focused on doing extensive reading as task given relating to the materials of the course in order to extend reading materials read by students outside of the classroom. She probably referred to some concepts of extensive reading offered by Day and Bamford (1998, 2004). Martini suggested; (1) Teachers should motivate students to read a lot of reading materials, (2) Teachers should be creative in finding interesting reading materials, (3) Teachers should be a good model, (4) 
Teachers should give a lot of reading tasks which can be read at home, (5) Teachers should control the students' reading activities outside of the classroom by using written report.

The other type of research is a comparative study. It is about comparative study on learning model in teaching reading at senor high school is as a study conducted by Sumadayo and Suwandi (2013). The Effect of Learning Model DRTA (Directed Reading Thinking Activity) toward students' reading comprehension ability seeing from their reading interest. They found that there is significant difference in the reading comprehension between students who are taught by learning model. The finding also indicates that group of students who have high reading interest and taught by DRTA learning model yields a better reading comprehension compared to the group of students who have high reading interest taught by FORTS and DRA learning model. There is an influence of the interaction model of learning for students' reading comprehension.

Antoni (2010) conducted a study on case study about the Exploration of EFL Teachers' Strategies in Teaching Reading Comprehension for junior high school students. The study found that the strategies teachers used in teaching reading comprehension are the activities done in pre, while, and post reading stages. For university level, Sri Andreani Astuti (2011) developed the students' interest by using reading box through their study. She found that reading box material for Reading II can be validated as the criteria. The product of Reading Box materials is useful for extensive reading. It is one of the way how to make students do extensive reading. They suggest that other English study program in other universities.

The other kinds of studies are about reflecting on character building, need analysis, reading habits, on line materials, the appropriate reading materials efforts for the student's interest and questions for students. Rozak (2012) conducted a study on "Developing Reading Narrative Text Materials for Eighth Graders of Junior High School Implemented with Character Building". They found that materials which are needed by eighth grade students in central Java are folktale. They also found that the development of narrative reading text materials implemented with character building for eighth graders of junior high school is developed which suits with the syllabus and actively followed by students. It improves students' knowledge and introduces some character building points. The materials are effective and appropriate for eighth graders of junior high school. They suggest that it is important to improve the ability of students' language competency in order to encourage students to learn English. They also suggest that other writers are expected to conduct replication research to ensure whether the result of the research is significant and consistent or not.

A study about the students' reading habit and a model of teaching reading for university students was conducted by Iftanti (2012). She did a Survey of the English reading habits in Indonesia in order to answer the 
research questions whether the students have good English reading habits. She also wanted to find how the students' motivation to read mostly comes from school assignments. The study results that most of the EFL students do not indicate to have good English reading habits although they have formally learned English from Elementary school to University. It is also found that even though the students have positive beliefs about reading English, their motivation to read mostly comes from school assignments. She suggested that further studies on English teaching technique promote good English reading habits. She also suggested that further studies are expected to find factors contributing to the development of good English reading habits of the EFL students and enhance their intrinsic motivation to read not only for the sake of doing assignments.

A study relating to the use of online resources which was to cultivate reading habits and increase English literacy achievement was conducted by Diem (2012). She found that the use of libraries is influenced by the existence of important features of libraries such as acquisition or procurement of library materials which are relevant, sufficient length of service-time, and the provision of information and communication technology (ICT). She also found that reading attitude, reading habit, and reading achievement of the students of Senior High School in South Sumatera is still low. The last finding is about the significant difference between males and females in regard to reading attitude and habit, although both have more or less the same achievement in reading. Diem \& Sari (2012) also explored online resources for/with fifth graders to cultivate reading habits and increase English literacy achievement. They found that there were significant differences in reading habits and literacy achievement of the pupils who were exposed to using online resources and those who were not. They also found that reading habits or literacy achievement of the fifth grade pupils could increase. They suggested that exploring online resources for or with the pupils is beneficial and must be involved as one of teaching techniques to be used in English class. Another suggestion is that setting is as a vital means of a tool to develop young learners' reading habits and increase literacy achievement in this technological era.

The study about reading materials, especially about characteristic of reading materials was a study conducted by Arka et al (2013). The study is "Developing Reading Comprehension Materials for Reading I Course in the English Education Department of FKIP Mahasaraswati Universitas Denpasar. It aims to answer "What are the characteristics of the appropriate materials for Reading I Course in the English Department of FKIP Mahasaraswati Universitas Denpasar". The finding shows that the characteristics of the appropriate materials for Reading I Course in the English Department of FKIP Mahasaraswati Universitas Denpasar are: 1) Reading material must have an impact on the students, 2) Reading material must give exposure to real 
language, 3) Reading material must be developed with different levels of difficulties, 5) Reading materials must encourage the students to develop learning skills and strategies, 6) Reading material must be appropriate instruction, and 7) Reading material must be attractive. They suggested that further study still needs to be done to this particular material and lecturers and researchers are encouraged to develop their own materials for different levels of students and different focus. Based on the discussion about the studies before the current study on the exploration of the learners' extensive reading experience in order to see how it contributes to their English language competency and the practices in the Extensive Reading course. Therefore, we can analyze the strengths and weaknesses of the studies as well as the similarities and differences of the studies and the current studies as the objectives of this article.

The studies on teaching and learning reading in Indonesia have found that Indonesian senior high school as well as university students have problem in recognizing text organization. The studies also found that the students' problems were not only about text structure knowledge but also linguistic knowledge, content and world background knowledge. These are as their basic understanding about language.

The studies might have strengths and weaknesses that might be considered by further researchers on this area. Some indications from the study refer to its strength. The researchers had conducted researches on efforts to develop students' reading ability from different points of view. They studied about differences among the level of the students' ability in terms of linguistic knowledge, text structure knowledge, content and world background knowledge, the students' difficulty, the strategy used by the students. The researchers were also aware about learning English in Indonesia, especially reading English texts by Indonesian by conducting researches about reading strategy used by students in Indonesian (Bahasa Indonesia) and English.

The application of extensive reading have been trying to do by the previous researchers although it was in terms of reading materials chosen by the students in English course and the students were expected to read outside of the classroom (Martini, 2008). Astuti (2011) supported Martini's (2008) to attract the students' interest in reading by using reading box through their study. Furthermore, Damien (2012) developed Martini's (2008) and Astuti (2011) in different ways. She did not focus on extensive reading but what she did was in line with the concept of extensive reading. It was also in line with the use of technology as an alternative reading mode. She focused on using technology to attract the students' reading habits and skills. The studies on teaching and learning reading developed gradually on the interest in extensive reading for the focus of attracting the students' interest in reading as one of the criteria of extensive reading suggested by Bamford and Day (1998, 2004). This condition grew 
gradually supporting the concept of extensive reading. It may inspire the following researchers to conduct researches on the area of extensive reading from different point view. Especially, it is in line with the context and the issue of teaching and learning in Indonesia. This is as the strength of the studies on teaching and learning reading in Indonesia. However, the studies were not dealing with the exploration of extensive reading developing the Indonesian learners' competency.

Most of the studies were only about the students' ability and the efforts to increase the ability. There was no study about a case of learners in learning outside or inside of the classroom especially the practice of extensive developing their language competence. This kind of the study is expected to be conducted because it can be as a reference for teachers/ lecturers and language learners to be competent in the language learnt. On other hand, Antoni (2010) conducted a study on case study about the exploration of EFL teachers' strategies in teaching reading comprehension for junior high school students. She found that reading box material for Reading II can be validated as the criteria. The product of Reading Box materials is useful for extensive reading. It is one of the way how to make students do extensive reading. Therefore, the answer of the first question of this study "What were the strength and the weaknesses of the studies on teaching and learning reading in 2003 to 2013 is about these two terms. The strengths of the studies on teaching and learning reading in 2003 to 2013 were in terms of the topic of the studies indicating learning English in Indonesian context and the studies on extensive reading have been the interest the researchers while the weakness were in terms of the focus of the studies of extensive reading and the variation of the research design. This condition might give the opportunity to the following researchers to conduct the research on extensive reading in the appropriate research design to the topic and Indonesian context.

The former studies on extensive reading might be similar and different from the current study. They are similar in terms of concept of extensive reading but they are different in terms of the research design. The former studies are about giving treatment for extensive reading but the current study is in terms how extensive are practiced outside and inside the classroom. Besides, this study is also about the contribution of extensive reading in becoming competence in English.

Researches on teaching and learning reading in Indonesia were designed in order to improve learners' ability in English. This study on the area of teaching and learning reading in Indonesia found that the strengths of the studies on teaching and learning reading in 2003 to 2013 were in terms of the various topic of learning reading in Indonesian context and interest in extensive reading while the weakness were in terms of the focus of the studies of extensive reading and the research design. This is as the answer of the first research question "(1) What were the strengths and the weaknesses of 
the studies on teaching and learning reading in 2003 to 2013?" The analysis also shows the result that the similarities between the studies on teaching and learning reading in 2003 to 2013 and this current study in terms of the concept of extensive reading, however, they are different in terms of the research design. This is as the answer of the second question "How were the studies on teaching and learning reading in 2003 to 2013 similar and/ or different from the study on "a Case Study on Two Indonesian Learners' Extensive Reading in English Experiences towards Developing Reading Competency"

This condition might be as opportunity to the following researchers to conduct the research on extensive reading in the appropriate research design to the topic and Indonesian context. Especially, there was no study on the exploration of the EFL Indonesian learners' experiences in developing reading competence. It is possible to conduct a case study on Indonesian learners' extensive reading in English Experiences towards developing reading competency. It is suggested that that teachers, lecturers and the policy makers on language learning concern about how extensive reading is implemented. It is also suggested Indonesian learners do extensive reading continuously in their daily life. The more the learners read, the more they acquire the language, and the more they acquire the language, the more they develop their language competency. This process shows how extensive reading contributes to English competency.

\section{CONCLUSION AND SUGGESTION}

This article is based on the critical analysis on teaching and learning reading in Indonesia for "a Case Study on Two Indonesian Learners' Extensive Reading in English Experiences towards Developing Reading Competency." This article aims to describe how extensive reading contributes to English competency. The analysis shows that the strengths of the studies on teaching and learning reading in 2003 to 2013 were in terms of the various topic of learning reading in Indonesian context and interest in extensive reading while the weaknesses were in terms of the focus of the studies of extensive reading and the research design. The analysis also shows the result that the similarities between the studies on teaching and learning reading in 2003 to 2013 and this current study in terms of the concept of extensive reading. It is as the answer of the second research question. This condition might be as opportunity to the following researchers to conduct the research on extensive reading in the appropriate research design to the topic and Indonesian context. It is suggested that that teachers, lecturers and the policy makers on language learning concern about how extensive reading is implemented.

\section{REFERENCES}

Abidin Jafre Zainol Muhamad \& Riswanto. 2012. "The Use of Comprehension Strategies in 
Reading Academic Texts Among the Students of State College for Islamic Studies (STAIN) Bengkulu, Indonesia" International Journal of Humanities, January and Social Science, Vol 2, No.1.

Aebersold, J.A. \& Field L.M. 2011. From Reader to Reading Teacher. New York. Cambridge University Press.

Ali, Hapid. 2012. "The Use of Silent Reading in Improving Students' Reading Comprehension and their Achievement in TOEFL Score at a Private English Course". International Journal of Basic and Applied Science, July, Vol. 1, No. 1.

Anderson, J. Neil and Nunan, David. 2008. Practical Englis Language Teaching Reading. McGraw-Hill ESL/ELT. New York.

Antoni, Nurman. 2010. "Exploring EFL Teachers" Strategies in Teaching Reading Comprehension Oktober" Journal Penelitian Pendidikan, Vol.11, No.2.

Arka I M, Padmadewi N Ni, Putra Adi Jaya I N. 2013. "Developing Reading Comprehension Materials for Reading I Course in the English Education Department of FKIP Mahasaraswati Universitas Denpasar". Jurnal Pendidikan Ganesha Vol .1.
Astuti Praba Utari \& Andreani Sri . 2011 "Reading Box for the Students Interest on Reading" Bahasa dan Seni, 39 (2).

Bamford, Julan and Day,R. Richard. 2004. Extensive Reading Activities for Teaching Language. Cambridge University Press. UK.

Bamford, Julan and Day, R. Richard1998. Extensive Reading Activities in the Second Language Classroo. Cambridge University Press. UK.

Brown, Douglas, H. 2001. Teaching by Principles an Interactive Approach to Language Pedagogy. Pearson Education Inc. New York.

Byrness, P. James and Wasik A. Barbara. 2009. Language and Literacy Development. The Guilford, New York.

Debora,Flora \& Divina Marsha Floris. 2009 "A Study on the Reading Skills of EFL University Students". TEFLIN Journal, February, Vol.20, No.1.

Diem Dahlan Chuzaimah. 2012. "How the Presence of Technologically Supported Library Influences High School Students' Reading Habits and Skills". Global Advanced research Journal. September, Vol. 1(1). 
Diem Dahlan Chuzaimah. Sari Novita Revi. 2012. "Exploring Online Resources for/with Fifth Graders to Cultivate Reading Habits and Increase English Literacy Achievement" Global Advanced research Journal, September Vol. 1(3).

Fitrawati. "Improving Senior High School Students' Reading Comprehension through Reading Strategies Derived from Genre Based Approach, "Jurnal Bahasa dan Seni Vol.10, No.2.

Hamra Afifudin \& Syatriana Eny. 2010. "Developing a Model of Teaching Reading Comprehension for EFL Students “. TEFLIN Journal, February Vol.21, No.1.

Hamra Arrifuddin \& Syatriana Eny. 2012 "A Model of Reading Teaching for University EFL: Need Analysis and Model Design". English Language Teaching; Vol.5. No. 10.

Hedgcock. S. John and Ferris R. Dana. 2009. Teaching Readers of English, Students, Texts, and Contexts, Routledge, New York.

Hedge, Tricia. 2007. Teaching and Learning in the Language Classroom. Oxford University Press. New York.

Iftanti, Erna. 2012. "A Survey of the English Reading Habits in
Indonesia" TEFLIN Journal, July, Vol. 23, No. 2.

Martini. 2008. "The implementation of Extensive Reading Task to Improve Student's Reading Motivation at Accounting Depatment, Padang State Polytechnic". Jurnal Akutansi dan Manajemen, Desember, Vol 3 No. 1.

Nuthall, Christine 1982. Teaching Reading Skills in a Foreign Language. Heinemann Publishers. London.

Sunggingwati Dyah \& Nguyen Hoa Thi Mai. 2013. "Teachers' Questioning in Reading Lessons: A Case Study in Indonesia" Electronic of Foreign Language Teaching., Vol. 10. No.1

Miranti Eka Putri. 2008 "Using the Immediate Written Recall to Enhance Students' Reading Comprehension of English Foreign Language Teaching in Indonesia" Jurnal Perspektif, Vol. XI, No.

Rozak Refi Ranto, Ngadiso \&l AsibAbdu "Developing Reading Narrative Text Materials for Eighth Graders of Junior High School Implemented with Character Building" English Education Journal 2 (2) 2012.

Sulistyo H.Gusnadi and Suharmanto. 2007. "Archetypal EFL Readers: Preliminary 
Emperical Evidence Substantiated

from Selected Discriminating Variables" TEFLIN Journal, February, Vol. 18, No. 1.

Vianty Machdalena. 2007. "The Comparison of Students' Use of Metagnitive Reading Strategies between Reading in Bahasa Indonesia and in English" International Education Journal, 8 (2).

Sumadayo Samsu, Slamet St Y., Nurkamto Joko, \& Suwandi Sarwiji. 2013 "The Effect of Learning Model DRTA (Directed Reading Thinking Activity) toward Students' Reading Comprehension Ability Seeing from Their Reading Interest" Journal of Education and Practice, Vol.4, No. 8. 